\title{
Cultured human chromaffin cells grafted in spinal subarachnoid space relieves allodynia in a pain rat model
}

\author{
Younghoon Jeon ${ }^{1}$, Woon Yi Baek ${ }^{2}$, Seung Hyun Chung ${ }^{3}$, Nari Shin ${ }^{4}$, Hye Rim Kim ${ }^{4}$, and Soon Ae Lee \\ Department of Anesthesiology and Pain Medicine, ${ }^{1}$ Kyungpook National University School of Dentistry, ${ }^{2}$ Kyungpook National \\ University School of Medicine, Daegu, ${ }^{3}$ Dongguk University Ilsan Hospital, Dongguk University College of Medicine, Goyang, \\ ${ }^{4}$ Seoul National University Hospital, Seoul, ${ }^{5}$ Center for Liver Cancer, National Cancer Center, Goyang, Korea
}

Background: Implantation of xenogenic chromaffin cells into the spinal subarachnoid space can produce analgesia in neuropathic pain models. However, transplantation of xenogeneic chromaffin cell has a potential risk of viral or bacterial infections from animals to humans including encephalopathy due to prion transmission. The aim of this study was to investigate the possibility of developing a homogeneic source of therapeutic chromaffin cells.

Methods: Anti-allodynic effects of human chromaffin cells (HCCs) were evaluated in a neuropathic pain model in rats induced by chronic constriction injury of the sciatic nerve. HCCs encapsulated with alginate-poly-L-lysinealginate were intrathecally implanted into rats $(\mathrm{n}=10)$, while empty capsules were intrathecally implanted as a control $(\mathrm{n}=8)$. Levels of norepinephrine from encapsulated HCCs before and after nicotinic stimulation were measured. We then perfomed a behavior test (cold allodynia) with acetone. In addition, to assess the potential contribution to pain reduction of opioid peptides released from the HCCs, all animals were injected with naloxone.

Results: The concentration of norepinephrine after nicotine stimulation was significantly increased compared to basal levels. Intrathecal implantation of encapsulated HCCs, significantly reduced cold allodynia as compared to rats receiving empty capsules $(\mathrm{P}<0.05)$. Fifteen minutes after the injection of naloxone, cold allodynia significantly decreased in rats with HCCs $(\mathrm{P}<0.05)$, while the degree of cold allodynia in control animals was unaltered.

Conclusions: From these results, it appears that HCCs have a possibility as an analgesic source for transplants delivering pain-reducing neuroactive substances. (Korean J Anesthesiol 2011; 60: 357-361)

Key Words: Analgesics, Chromaffin cells, Pain, Transplants.

Received: October 26, 2010. Revised: December 14, 2010. Accepted: December 15, 2010.

Corresponding author: Soon Ae Lee, M.D., Department of Anesthesiology and Pain Medicine, Center for Liver Cancer, National Cancer Center, 323, Ilsan-ro, Ilsandong-gu, Goyang 410-769, Korea. Tel: 82-31-920-1450, Fax: 82-31-920-1463, E-mail: anesth-lsa@ncc.re.kr

(c) This is an open-access article distributed under the terms of the Creative Commons Attribution Non-Commercial License (http:// creativecommons.org/licenses/by-nc/3.0/), which permits unrestricted non-commercial use, distribution, and reproduction in any medium, provided the original work is properly cited. 


\section{Introduction}

Despite recent advances in our understanding of chronic pain mechanisms, the management of chronic pain, particularly neuropathic pain, is far from being resolved with currently available therapeutic regimens. Therefore, chronic pain is a major medical and societal problem that results in enormous financial costs $[1,2]$. Transplantation of cells that secrete neuroactive substances with analgesic properties into the central nervous system (CNS) has been considered to be a promising therapy for the long-term treatment of chronic pain $[3,4]$. Intrathecally administered bovine adrenal chromaffin cells were reported to reduce neuropathic pain in rats by producing antinociceptive substances, such as catecholamines and met-enkephalin $[5,6]$.

Due to the low number of available grafts, sources other than human cells, that is xenogenic donors have to be considered for this therapeutic approach $[5,6]$. However, the major problem associated with xenogenic cell transplantation has been the long-term survival of the transplanted cells and the risk of the infection from viruses or pathogens, such as mad cow disease. Therefore, homologous transplant may be one of the safest methods for clinical applications. In this study, we investigate the analgesic effect of human chromaffin cells (HCCs) on neuropathic pain in rats with chronic constrictive injury (CCI) of the sciatic nerve.

\section{Materials and Methods}

Approval was obtained from our Ethics Committee, and written informed consent was obtained from all patients. The study protocol was also approved by our Animal Care Committee.

\section{Purification of HCCs}

Adrenal chromaffin glands from the adrenal mass of patients with renal cell cancer were isolated and transported at $4^{\circ} \mathrm{C}$ in Locke's solution (154 mM NaCl, 5.6 mM KCl, 3.6 mM NaHCO${ }_{3}$, $5.6 \mathrm{mM}$ glucose, and $5 \mathrm{mM}$ HEPES) to the laboratory within $1 \mathrm{~h}$. After removing connective tissue and blood vessels using an aseptic technique, the exterior surfaces of the exposed adrenal glands were rinsed and perfused with Locke's solution including $1 \%$ penicillin/streptomycin (10,000 unit/ml; Gibco, Carlsbad, CA, USA). The glands were then incubated in digestion buffer $(0.2 \%$ [wt/vol] collagenase, Worthington, Lakewood, NJ, USA in Locke's solution) at $37^{\circ} \mathrm{C}$ for $20 \mathrm{~min}$. The adrenal medullary tissue was dissected from the surrounding cortical tissue, triturated, and incubated in digestion buffer at $37^{\circ} \mathrm{C}$ for $1 \mathrm{~h}$. The digested medullary tissue was then passed through a polypropylene screen (100 $\mu \mathrm{m}$ mesh). The cell suspension was centrifuged for $5 \mathrm{~min}$ at $70 \times \mathrm{g}$ in $40 \mathrm{ml}$ Locke's solution. The supernatant was discarded and the cell pellet was resuspended and centrifuged for $5 \mathrm{~min}$. The cell pellet was then resuspended in Dulbecco's Modified Eagle's Medium (DMEM)/ F12 (Invitrogen, Grand Island, NY, USA) supplemented with $10 \%$ fetal bovine serum (FBS, Invitrogen) and inoculated into non-tissue culture dishes at a density of $\sim 5 \times 10^{6}$ cells/dish. The cells were incubated at $37^{\circ} \mathrm{C}\left(5 \% \mathrm{CO}_{2}\right)$ in a humidified, enriched environment overnight to allow for differential adherence of unwanted cell types such as fibroblasts and endothelial cells. The next day, the less adherent chromaffin cells were separated by gentle agitation and were plated into non-tissue culturetreated Petri dishes at the same density after centrifugation at 80 $\times \mathrm{g}$ at $25^{\circ} \mathrm{C}$ for $10 \mathrm{~min}$.

The procedure was repeated once again to obtain highly purified chromaffin cells and replated into tissue culturetreated dishes at the same density in DMEM/F12 including $10 \%$ FBS, antibiotics (100 $\mu \mathrm{M} / \mathrm{ml}$ penicillin/streptomycin, Gibco), and antimytotic agents $\left(10^{-5} \mathrm{M}\right.$ uridine and $10^{-5} \mathrm{M}$ 5-fluoro5deoxyurdine, Sigma-Aldrich, St. Louis, MO, USA). A $10 \mu \mathrm{l}$ aliquot of cells was stained with trypan blue solution ( $0.2 \%)$ and counted in a hemocytometer to estimate both yield and cell viability. To confirm the purification of HCCs, a $10 \mu \mathrm{l}$ aliquot was stained with neutral red $(0.9 \%$ in phosphate buffered solution), a dye that selectively reacts with monoaminecontaining cells. In all, 95\% HCCs were obtained through the multiple purification process.

\section{Norepinephrine}

Function of HCCs inside the capsules was evaluated by measuring the release of catecholamine by nicotine stimulation in vitro for 30 days. At various times during cell culture, microencapsulated HCCs were incubated in 12-well plates at a density of $1 \times 10^{6}$ cells/well and washed three times with HBSS (Hanks' balanced salt solution, Gibco) containing $50 \mu \mathrm{M}$ ascorbic acid. They were incubated in $1 \mathrm{ml} \mathrm{HBSS}$ for $60 \mathrm{~min}$ at $37^{\circ} \mathrm{C}$ to obtain basal levels of catecholamines. These samples were collected, filtered with $0.2 \mu \mathrm{m}$ filter and immediately frozen in at $-70^{\circ} \mathrm{C}$. After basal sampling, HCCs were incubated in $1 \mathrm{ml}$ HBSS with $50 \mu \mathrm{M}$ nicotine for $60 \mathrm{~min}$ under the same condition as the basal samples. Catecholamine levels were quantified using reverse phase high-performance liquid chromatography (HPLC, BAS-480; Bioanalytical Systems, West Lafayette, IN, USA) with electrochemical detection. The mobile phase was $0.07 \mathrm{M} \mathrm{NaH}_{2} \mathrm{PO}_{4}, 0.2 \mathrm{mM}$ octylsodium sulfate, $0.1 \mathrm{mM}$ EDTA, and $8 \%$ methanol. The flow rate through a Waters Resolve $\mathrm{C} 18 \mu$ Bondapak column was $1.0 \mathrm{ml} / \mathrm{min}$. The electrochemical detector was set at $+0.6 \mathrm{mV}$ versus an $\mathrm{Ag}-\mathrm{AgCl}$ 
reference electrode.

\section{Microencapsulation of HCCs}

After 3-4 days of primary culture, HCCs were suspended in $1.4 \%$ (wt/vol) sodium alginate (Junsei, Tokyo, Japan) and $0.85 \%$ $\mathrm{NaCl}$ at a density of 5,106 cells/ml. Spherical droplets of this suspension were formed by extrusion through a syringe pump and gelled in $1.1 \% \mathrm{CaCl}_{2}$. Cell capsules were microcapsules having a diameter ranging from 100-300 mm. After washing twice in $0.85 \% \mathrm{NaCl}$, the capsules were coated with $0.05 \%$ poly-l-lysine (Sigma, St. Louis, MO, USA). The coated capsules were washed with $0.85 \% \mathrm{NaCl}$ and then suspended for $7 \mathrm{~min}$ in $0.12 \%$ sodium alginate, which formed the outer layer of the membrane. After another wash with $0.85 \% \mathrm{NaCl}$, the capsules were then treated with $1 \mathrm{mM}$ sodium citrate $(\mathrm{pH}$ 7.4) for 2 min. The sodium citrate was removed by washing twice with $0.85 \% \mathrm{NaCl}$ and the encapsulated cell suspension was then distributed equally into 6-well culture dishes with DMEM/ F12 supplemented with $10 \%$ FBS. The encapsulated cells were maintained at $37^{\circ} \mathrm{C}\left(95 \%\right.$ relative humidity, $\left.5 \% \mathrm{CO}_{2}\right)$.

Animals: Male Sprague-Dawley rats (200 to $300 \mathrm{~g}$, Taconic) were group-housed with two per polycarbonate cage, in a temperature controlled room with a 12 : 12-hour light/dark cycle. Food and water were available ad libitum. All surgical procedures were performed by trained surgeons using aseptic techniques and anesthesia (pentobarbital, $50 \mathrm{mg} / \mathrm{kg}$ intraperitoneally, supplemented as necessary).

Neuropathic pain model: For the CCI surgery, the left common sciatic nerve was exposed at the mid-thigh level under 25x magnification. Four ligatures of size 40 chromic gut were tied loosely around the nerve with $1 \mathrm{~mm}$ spacing between knots so that the epineural circulation was preserved. At the time of tying, the ligatures just barely reduced the nerve diameter [7]. Over time, the ligatures evoked intraneural edema, resulting in constriction of the nerve. After surgery, the wound was washed with saline and the layers (fascia and skin) were closed with size 30 silk thread.

Implantation: One week after CCI surgery, rats were randomly allocated into the two groups. The cell loaded group received encapsulated chromaffin cells $(n=10)$, while control group received empty capsules $(n=8)$. The microcapsules were implanted into the lumbar subarachnoid space. A posterior L5 laminectomy was performed and then a small incision was made in the dura. Approximately 500 microcapsules $\left(5 \times 10^{2}\right.$ cells/capsule) were implanted into the subarachnoid space via a 24-gauge teflon catheter. After surgery, the wound was washed with saline and the layers (fascia and skin) were closed with size 30 silk thread.

Cold allodynia: A drop of acetone solution (97.7\%) was applied under the hind paw:acetone evaporates quickly producing a sensation of cold. The duration of the withdrawal response (cold allodynia) was recorded with an arbitrary minimum value of $0.5 \mathrm{~s}$ and a maximum value of $40 \mathrm{~s}$.

Opioid antagonist (Naloxone): To assess the potential contribution to pain reduction by opioid peptides released from the implanted microcapsules, all animals were injected with the opioid antagonist, naloxone, during the peak period of analgesia exerted by the chromaffin cells. Following behavioral testing 3 weeks after nerve ligation ( 2 weeks after implantation), the animals were injected with naloxone $(2.0 \mathrm{mg} / \mathrm{kg}$, S.C.). Fifteen minutes later, the degree of cold allodynia was assessed.

Data analysis: Results are reported as means \pm SD. Statistical analysis of the cold allodynia data was performed using SPSS for Windows version 10.0 (SPSS Inc., Chicago, IL). We applied a student $t$ test to compare the values from two independent samples and a paired t test to compare the values of means from two related samples. Statistical significance was considered when $\mathrm{P}<0.05$.

\section{Results}

\section{Norepinephrine}

Quantities of norepinephrine are shown in Fig. 1. The concentration of norepinephrine after nicotine stimulation was significantly increased compared to basal levels $(\mathrm{P}<0.05)$.

\section{Cold allodynia}

As shown in Fig. 2, animals exhibited little or no response to a

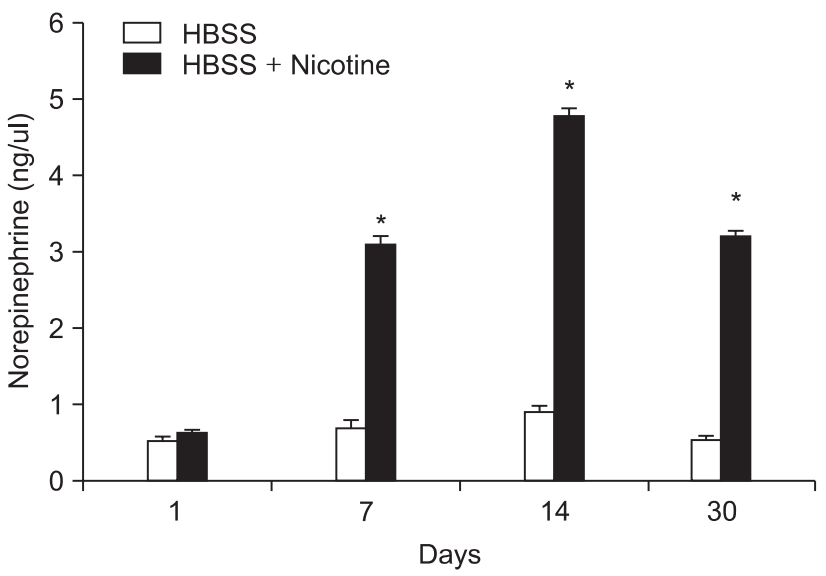

Fig. 1. Norepinephrine release from encapsulated human chromaffin cells in vitro. The levels of norepinephrine in Hank's buffered salt solution (HBSS) were evaluated 1, 7, 14, and 30 days after encapsulation by HPLC. ${ }^{*} \mathrm{P}<0.05$ compared with pre-nicotine stimulation. 


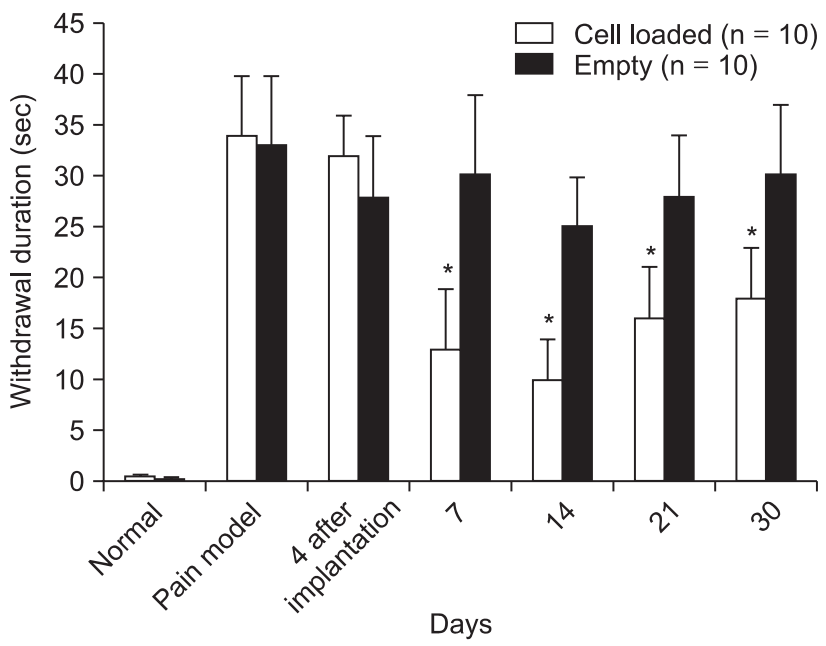

Fig. 2. Rats developed a cold allodynic response to acetone after ligation of the sciatic nerve. Rats that received microencapsulated human chromaffin cells showed a significant decrease in the withdrawal response to acetone, as compared to the control group $(* P<0.05)$. The data are presented as means \pm SD. Significant withdrawal time differences between the cell transplantation and control groups were seen $(* \mathrm{P}<0.05$ vs Control).

cold stimulus (acetone) prior to ligation of the sciatic nerve. One week after nerve ligation, there was an enhanced withdrawal response to acetone evaporation. After the implantation of microencapsulated HCCs, the response duration was significantly reduced as compared to the controls which received empty microcapsules $(\mathrm{P}<0.05$, Fig. 2$)$.

\section{Opioid antagonist test}

As shown in Fig. 3, fifteen minutes after the injection of naloxone, the degree of cold allodynia in control animals was unaltered. However, cold allodynia significantly increased after naloxone injection in rats with HCCs $(\mathrm{P}<0.05)$. The severity of cold allodynia in rats with HCCs was less than in the control animals $(\mathrm{P}<0.05)$.

\section{Discussion}

We observed that, in vitro, nicotine induced a significant release of catecholamine from HCCs, and in vivo, we observed a significant decrease in cold allodynia in rats implanted with HCCs. Chromaffin cells that release various pain suppressing substances originate from ectoderm of the neural crest [8]. Therefore, the possibility of an immune reaction is low within the central nerve system, making the chromaffin cells suitable for transplant in subarachnoid space. In addition, the bloodbrain-barrier exists in the subarachnoid space which makes them immuno-privileged [9]. Although intrathecally implanted

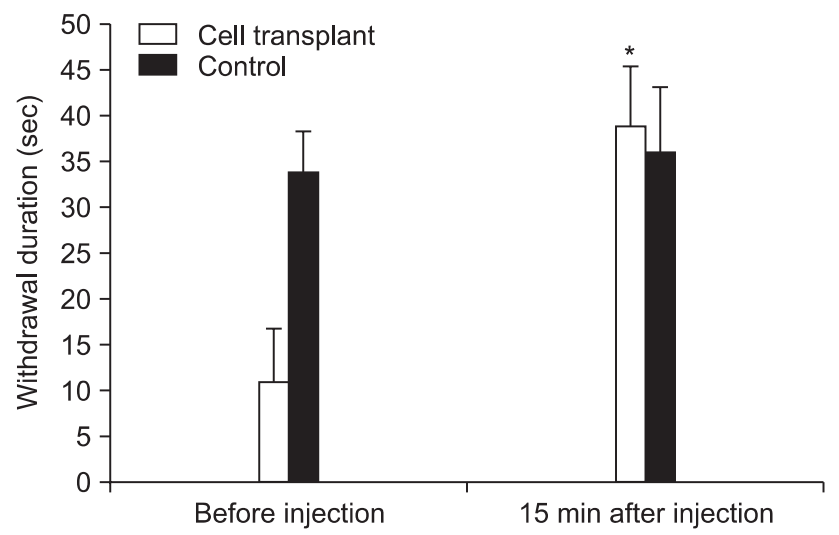

Fig. 3. Effect of naloxone on the degree of cold allodynic response to acetone after nerve ligation in rats with microencapsulated chromaffin cells. ${ }^{*} \mathrm{P}<0.05$ compared to pre-injection of naloxone $(2.0$ $\mathrm{mg} / \mathrm{kg}$, S.C.). The data are presented as means \pm SD.

xenogenic chromaffin cells produced analgesic effects in the neuropathic pain models [10], there is a possibility of rejection of these xenogenic implants by the host. In addition, xenogenic implants can be a source of viral infection or pathogens. Thus, homologous transplant is considered one of the safest methods despite donor limitation.

To protect HCCs from the immune cells of rat, HCCs were capsulated within a semipermeable polymer membrane made of alginate-poly-L-lysine-alginate (APA) $[6,11]$. Additionally, this isolation method forms a proper environment for survival of the implant by allowing diffusion of oxygen, nutrients and growth factors from the host into the implant, as well as allows the discharge of waste biproducts out of the HCCs. The encapsulation has two strategies: the first is macrocapsulation which encloses cells into a flat sheet membrane with a semipermeable nature [12] and the other is microcapsulation which encloses cells into round-shaped mini capsules $[6,11,13,14]$. However, microcapsules may be a superior system for cell transplantation than macrocapsules for delivery of therapeutic substances and long-term survival [6].

In this study, we observed that cold allodynia in rats implanted with HCCs was significantly lower 3 to 30 days after transplantation when compared with the control group. In addition, the encapsulated HCCs in vitro significantly produced norepinephrine after nicotine stimulation up to 30 days after encapsulation. With his finding, we presumed that microencapsulated chromaffin cells were able to produce high levels of catecholamines in the long term, thereby potentially reducing pain. Indeed, norepinephrine in the spinal cord induces analgesia in the several animal pain models $[15,16]$. Descending inhibitory tracts originating from cell bodies in the periaqueductal gray,reticular formation and nucleus magnus project spinal dorsal horn. These inhibitory tracts contain a 
variety of neurotransmitters including catecholamines and opioids, which play an important role in nociceptive responses $[17,18]$. In this study, after naloxone administration, the withdrawal duration time from acetone in rats with implanted HCCs significantly increased. From these data, we speculate that one of analgesic materials released from HCCs may be an opioid peptide such as met enkephalin $[5,6]$.

In conclusion, although HCCs has the limitation of supply, they have the advantage of decreased infection risk and tissue rejection resulting from heterologous transplant. Therefore, this could become a new therapy for pain treatment with guaranteed stability and effective pain suppression when transplanted into the human body.

\section{References}

1. Bowsher D. Pain syndromes and their treatment. Curr Opin Neurol Neurosurg 1993; 6: 257-63.

2. McLeod JG. Investigation of peripheral neuropathy. J Neurol Neurosurg Psychiatry 1995; 58: 274-83.

3. Sol JC, Sallerin B, Larrue S, Li RY, Jozan S, Tortosa F, et al. Intrathecal xenogeneic chromaffin cell grafts reduce nociceptive behavior in a rodent tonic pain model. Exp Neurol 2004; 186: 198-211.

4. Aebischer P, Buchser E, Joseph JM, Favre J, de Tribolet N, Lysaght M, et al. Transplantation in humans of encapsulated xenogeneic cells without immunosuppression. A preliminary report. Transplantation 1994; 58: 1275-7.

5. Sagen J, Wang H, Tresco PA, Aebischer P. Transplants of lmmunologically isolated xenogeneic chromaffin cells provide a long-term source of pain-reducing neuroactive substances. J Neurosci 1993; 13: 2415-23.

6. Jeon Y, Kwak K, Kim S, Kim Y, Lim J, Baek W. Intrathecal implants of mcroencapsulated xenogenic chromaffin cells provide a long-term source of analgesic substances. Transplant Proc 2006; 38: 3061-5.
7. Bennett GJ, Xie YK. A peripheral mononeuropathy in rat that produces disorders of pain sensation like those seen in man. Pain 1988; 33: 87-107.

8. Huber K, Kalcheim C, Unsicker K. The development of the chromaffin cell lineage from the neural crest. Auton Neurosci 2009; 151: 10-6.

9. Aloisi F, Ambrosini E, Columba-Cabezas S, Magliozzi R, Serafini B. Intracerebral regulation of immune responses. Ann Med 2001; 33: 510-5.

10. Baek WY, Jeon YH, Mun CW, Han CG, Kim YM, Lim JO. Analgesic effect of transplanted adrenal medullary chromaffin cells in rats spinal cord. Korean J Anesthesiol 2001; 41: 490-4.

11. Baek WY, Kim HG, Kim YM, Lim JO, Jeon YH. Microencapsulated bovine adrenal medullary chromaffin cells transplanted into rat spinal cord alleviated cold allodynia. Korean J Anesthesiol 2004; 46 : 354-9.

12. Décosterd I, Buchser E, Gilliard N, Saydoff J, Zurn AD, Aebischer P. Intrathecal implants of bovine chromaffin cells alleviate mechanical allodynia in a rat model of neuropathic pain. Pain 1998; 76: 159-66.

13. Chang TM. Hybrid artificial cells: microencapsulation of living cells. ASAIO J 1992; 38: 128-30.

14. Lim F, Sun AM. Microencapsulated islets as bioartificial endocrine pancreas. Science 1980; 210: 908-10.

15. Yaksh TL, Reddy SV. Studies in the primate on the analgetic effects associated with intrathecal action of opiateds, alpha-adrenergic agonists and baclofen. Anesthesiology 1981: 54: 451-67.

16. Reddy SV, Maderdrut JL, Yaksh TL. Spinal cord pharmacology of adrenergic agonist-mediated antinociception. J Pharmacol Exp Ther 1980; 213: 525-33.

17. Zieglgänsberger W, Tulloch IF. The effects of methionine- and leucine-enkephalin on spinal neurones of the cat. Brain Res 1979; 167: 53-64.

18. Reddy SV, Maderdrut JL, Yaksh TL. Spinal cord pharmacology of adrenergic agonist-mediated antinociception. J Pharmacol Exp Ther 1980; 213: 525-33. 